Article

\title{
Evaluating Bioenergy Cropping Systems towards Productivity and Resource Use Efficiencies: An Analysis Based on Field Experiments and Simulation Modelling
}

\author{
Babette Wienforth ${ }^{1}$, Astrid Knieß ${ }^{1}$, Ulf Böttcher ${ }^{1}$ (D), Antje Herrmann ${ }^{2}$, Klaus Sieling ${ }^{1, *}$, \\ Friedhelm Taube ${ }^{3}$ and Henning Kage ${ }^{1}$ (iD \\ 1 Institute of Crop Science and Plant Breeding, Agronomy and Crop Science, Christian-Albrechts-University, \\ Hermann-Rodewald-Str. 9, 24118 Kiel, Germany; wienforth@pflanzenbau.uni-kiel.de (B.W.); \\ kniess@pflanzenbau.uni-kiel.de (A.K.); boettcher@pflanzenbau.uni-kiel.de (U.B.); \\ kage@pflanzenbau.uni-kiel.de (H.K.) \\ 2 Landesbetrieb Landwirtschaft Hessen, Landwirtschaftszentrum Eichhof, Schlossstr. 1, \\ 36251 Bad Hersfeld, Germany; antje.herrmann@llh.hessen.de \\ 3 Institute of Crop Science and Plant Breeding, Grass and Forage Science/Organic Agriculture, \\ Christian-Albrechts-University, Hermann-Rodewald-Str. 9, 24118 Kiel, Germany; ftaube@email.uni-kiel.de \\ * Correspondence: sieling@pflanzenbau.uni-kiel.de; Tel.: +49-(431)-880-3444; Fax: +49-(431)-880-1396
}

Received: 14 June 2018; Accepted: 10 July 2018; Published: 11 July 2018

check for updates

\begin{abstract}
Silage maize (Zea mays L.) is the dominating energy crop for biogas production due to its high biomass yield potential, but alternatives are currently being discussed to avoid environmental problems arising from maize grown continuously. This study evaluates the productivity and resource use efficiency of different bioenergy crops and cropping systems using experimental and simulation modelling derived data. The field experiment consisted of two years, two sites differing in soil texture and soil water availability, different cropping systems and increasing nitrogen $(\mathrm{N})$ supply. Continuous (two years) perennial ryegrass and two crop rotations including winter cover crops (double cropping system) and combining $\mathrm{C} 4$ and $\mathrm{C} 3$ crops were compared with continuous maize (maize-maize). The productivity of the crops and cropping systems in terms of dry matter (DM) yield was analyzed with respect to the fraction of light interception and light use efficiency (LUE). In addition, water use and water use efficiency (WUE), $\mathrm{N}$ uptake, and $\mathrm{N}$ use efficiency (NUE) were quantified. DM yield of the double cropping system was similar to that of continuous maize, due to a prolonged leaf area duration, compensating for the intrinsic lower LUE of C3 crops. Perennial ryegrass was less productive than the other crops/cropping systems. Nitrogen uptake and consequently $\mathrm{N}$ demand of perennial ryegrass and the $\mathrm{C} 3$ crops of the crop rotations were higher than for maize-maize. Groundwater recharge was mainly site-dependent, but was at both sites higher for maize than for the crop rotations or the perennial ryegrass system. Our results indicate that, in terms of biomass productivity, optimized rotations are feasible alternatives to maize-maize, but trade-offs exist in terms of water and $\mathrm{N}$ use efficiency.
\end{abstract}

Keywords: bioenergy; biomass; cropping systems; maize; wheat; grasses; water use efficiency; nitrogen use efficiency

\section{Introduction}

European Union energy policies, and particularly the energy policies in Germany, strongly promote energy production from renewable resources. Germany has recently become the 
world's most important producer of biogas (biomethane) [1]. The key substrate for German biogas plants is whole-crop maize silage [2]. This has resulted in a considerable increase in the acreage of maize (Zea mays L.), which is often cultivated in monoculture. Arising problems like high pest pressure and high nutrient losses may be overcome by using alternative crops and cropping systems with higher crop diversity [3]. Double- and inter-cropping or crop rotation systems have been proposed in general [4,5], and in particular for bioenergy cropping systems [3,6], because for biomethane production, vegetative biomass can be used and the completion of the whole growth cycle is not necessary. Crop rotations combining C 3 winter cover crops and annual C4 and C 3 main crops may be advantageous if low temperatures during parts of the growth period limit the productivity of the thermophile C4 crop maize [7-9]. Including cold tolerant C3 crops within the crop rotation may prolong the leaf area duration and light interception and thereby the overall productivity [4].

On the other hand this may lead to a higher water demand, possibly resulting in less ground water recharge or temporary drought stress, depending on precipitation and soil water storage capacity. The higher $\mathrm{N}$ concentration of $\mathrm{C} 3$ crop leaves [10-12] may boost $\mathrm{N}$ demand and thereby lower the $\mathrm{N}$ efficiency and indirectly affect the greenhouse gas balance of the cropping system negatively.

Some key variables of resource use and resource use efficiency like the cumulative radiation interception and the components of the water balance are difficult to measure in the field. Crop and cropping system simulation models [13] can be used to estimate these variables, but may not be available for every crop in a cropping system experiment. Alternatively, empirical experimental data describing crop productivity may be combined with components of simulation models [14]. Especially, high frequency non-destructive measurements offer the possibility to additionally include dynamic aspects of crop growth into the analysis.

The objective of this paper was (1) to evaluate the productivity (DM yield) of different cropping systems for biogas production; (2) to identify some key variables of resource use (e.g., radiation interception) and resource use efficiency (water, transpiration and $\mathrm{N}$ use efficiency); and (3) to analyze resource limitations on DM accumulation. Thereby, the experimental data were analyzed by a simulation model taking sequently measured crop variables as input. In other studies based on the same field experiments, aspects of different $\mathrm{N}$ sources including biogas residues on productivity [15,16], $\mathrm{N}$ losses due to leaching [17], $\mathrm{NH}_{3}$ volatilization [18], $\mathrm{N}_{2} \mathrm{O}$ emissions [19], and their effects on a life cycle assessment (LCA) analysis [20] have already been given.

\section{Materials and Methods}

\subsection{Field Experiment}

\subsubsection{Sites and Weather Conditions}

The two experimental sites differ mainly in their soil types and, to a small degree, in terms of their climatic conditions. The soil at Hohenschulen (HS, $54^{\circ} 18^{\prime} \mathrm{N}, 9^{\circ} 58^{\prime} \mathrm{E}$ ) was a sandy loam soil (Luvisol), that at Karkendamm (KD, 53 $55^{\prime} \mathrm{N}, 9^{\circ} 56^{\prime} \mathrm{E}$ ) a sandy soil (Gleyic Podzol), resulting in different soil water storage capacities of $166 \mathrm{~mm}$ (HS) and $125 \mathrm{~mm}$ (KD), assuming an effective rooting depth of $100 \mathrm{~cm}$ at both sites. At KD, the groundwater table fluctuates between $80 \mathrm{~cm}$ in winter and $240 \mathrm{~cm}$ during summer. Additionally, the soil at the KD site is characterized by a soil pan from ferrous oxides at $30-40 \mathrm{~cm}$ soil depth.

At KD mean air temperatures and precipitation were in both experimental years slightly higher, whereas average wind speed was lower than at HS (Table 1). At both sites, the measured averaged air temperatures in 2007 were approx. $1.7^{\circ} \mathrm{C}$ higher and in 2008 approx. $1.1{ }^{\circ} \mathrm{C}$ higher than the long-term average. Both sites received significantly higher amounts of precipitation in 2007 (approx. plus $150 \mathrm{~mm}$ at $\mathrm{HS}$ and plus $300 \mathrm{~mm}$ at KD). Drought periods occurred during spring, with monthly amounts of precipitation of $<10 \mathrm{~mm}$ in April 2007 and $<20 \mathrm{~mm}$ in May 2008. 
Table 1. Monthly average air temperature, wind speed, accumulated global radiation and accumulated precipitation given for the experimental periods and both sites Hohenschulen (HS) and Karkendamm (KD).

\begin{tabular}{|c|c|c|c|c|c|c|}
\hline Site & Year & Month & $\begin{array}{c}\text { Air Temperature } \\
\left({ }^{\circ} \mathrm{C}\right)\end{array}$ & $\begin{array}{l}\text { Global Radiation } \\
\left(\mathrm{MJ} \mathrm{m}^{-2}\right)\end{array}$ & $\begin{array}{l}\text { Precipitation } \\
\quad(\mathrm{mm})\end{array}$ & $\begin{array}{l}\text { Wind Speed } \\
\left(\mathrm{m} \mathrm{s}^{-1}\right)\end{array}$ \\
\hline \multirow[t]{27}{*}{ HS } & \multirow[t]{5}{*}{2006} & August & 16.6 & 361 & 155 & 2.6 \\
\hline & & September & 17.0 & 315 & 37 & 3.5 \\
\hline & & October & 12.5 & 130 & 88 & 3.0 \\
\hline & & November & 7.7 & 57 & 66 & 3.5 \\
\hline & & December & 6.5 & 30 & 54 & 4.1 \\
\hline & \multirow[t]{12}{*}{2007} & January & 5.5 & 42 & 142 & 6.3 \\
\hline & & February & 3.7 & 94 & 53 & 4.0 \\
\hline & & March & 7.2 & 272 & 56 & 4.3 \\
\hline & & April & 10.3 & 455 & 3 & 3.4 \\
\hline & & May & 12.6 & 471 & 94 & 2.6 \\
\hline & & June & 16.3 & 436 & 120 & 2.5 \\
\hline & & July & 16.2 & 436 & 189 & 3.2 \\
\hline & & August & 17.0 & 376 & 59 & 3.2 \\
\hline & & September & 13.1 & 264 & 71 & 3.7 \\
\hline & & October & 8.9 & 173 & 25 & 2.3 \\
\hline & & November & 5.0 & 85 & 38 & 3.6 \\
\hline & & December & 3.3 & 30 & 77 & 2.8 \\
\hline & \multirow[t]{10}{*}{2008} & January & 4.4 & 41 & 64 & 4.6 \\
\hline & & February & 4.7 & 117 & 40 & 4.5 \\
\hline & & March & 4.3 & 242 & 62 & 4.3 \\
\hline & & April & 7.6 & 423 & 41 & 3.0 \\
\hline & & May & 13.7 & 695 & 19 & 2.6 \\
\hline & & June & 15.4 & 647 & 42 & 3.4 \\
\hline & & July & 17.6 & 561 & 69 & 3.2 \\
\hline & & August & 16.6 & 364 & 131 & 3.1 \\
\hline & & September & 13.2 & 284 & 65 & 2.6 \\
\hline & & October & 9.5 & 152 & 124 & 3.2 \\
\hline Site & Year & Month & $\begin{array}{c}\text { Air Temperature } \\
\left({ }^{\circ} \mathrm{C}\right)\end{array}$ & $\begin{array}{l}\text { Global Radiation } \\
\left(\mathrm{MJ} \mathrm{m}^{-2}\right)\end{array}$ & $\begin{array}{l}\text { Precipitation } \\
\text { (mm) }\end{array}$ & $\begin{array}{l}\text { Wind Speed } \\
\left(\mathrm{m} \mathrm{s}^{-1}\right)\end{array}$ \\
\hline \multirow[t]{27}{*}{$\mathrm{KD}$} & \multirow[t]{5}{*}{2006} & August & 17.2 & 443 & 184 & 2.1 \\
\hline & & September & 16.9 & 364 & 56 & 2.1 \\
\hline & & October & 12.7 & 149 & 81 & 2.2 \\
\hline & & November & 8.0 & 70 & 70 & 2.7 \\
\hline & & December & 6.7 & 44 & 69 & 2.8 \\
\hline & \multirow[t]{12}{*}{2007} & January & 5.4 & 54 & 186 & 4.2 \\
\hline & & February & 3.7 & 93 & 73 & 2.8 \\
\hline & & March & 7.2 & 306 & 66 & 2.9 \\
\hline & & April & 10.9 & 487 & 9 & 2.3 \\
\hline & & May & 13.3 & 545 & 81 & 1.8 \\
\hline & & June & 16.9 & 501 & 108 & 1.7 \\
\hline & & July & 16.5 & 490 & 154 & 1.5 \\
\hline & & August & 17.4 & 443 & 89 & 1.1 \\
\hline & & September & 13.9 & 275 & 86 & 1.6 \\
\hline & & October & 9.1 & 174 & 23 & 1.2 \\
\hline & & November & 5.1 & 84 & 66 & 2.1 \\
\hline & & December & 3.7 & 38 & 98 & 2.2 \\
\hline & \multirow[t]{10}{*}{2008} & January & 5.1 & 50 & 78 & 3.4 \\
\hline & & February & 4.8 & 114 & 38 & 2.7 \\
\hline & & March & 4.6 & 227 & 93 & 3.0 \\
\hline & & April & 7.6 & 400 & 30 & 2.1 \\
\hline & & May & 13.4 & 703 & 12 & 1.8 \\
\hline & & June & 16.1 & 638 & 44 & 1.8 \\
\hline & & July & 18.0 & 561 & 92 & 1.6 \\
\hline & & August & 16.8 & 382 & 124 & 1.3 \\
\hline & & September & 12.9 & 283 & 28 & 1.2 \\
\hline & & October & 9.3 & 154 & 110 & 1.8 \\
\hline
\end{tabular}




\subsubsection{Experimental Design}

The experiment was set as a randomized block design with four replications for each treatment. Plot size was $12 \mathrm{~m} \times 12 \mathrm{~m}$, divided into four strips with one strip for plant and soil sampling, one strip for harvest and the two outer strips for avoiding border effects. The main experimental factors were cropping system (CS) and level of N supply (N). The cropping systems (Figure 1), established in $\mathrm{HS}$ and KD, were different and chosen according to the soil types, but with 'continuous' silage maize (cv. Ronaldino, FAO class 240) in both experimental years (CS1) as a common system for both sites. At the KD site continuous maize CS1 was compared with a four-cuts per year sward of perennial grassland (CS4) consisting of two ryegrass varieties (Lolium perenne L. cv. Fennema and Edda). At the HS site, system CS1 was compared with a rotation consisting of silage maize (cv. Salgado, FAO class 200) followed by a winter wheat (Triticum aestivum L. cv. Biscay) used as whole plant silage and a two-cuts per year Italian ryegrass (Lolium multiflorum Lam. cv. Gisel) as a winter intercrop (CS2) and by a mixed food/biomass rotation with silage maize (cv. Ronaldino, FAO class 240 ), grain wheat (Triticum aestivum L. cv. Biscay) followed by yellow mustard (Sinapis alba L. cv. Accent) as a catch crop (CS3). The experiment was established in autumn 2006 and ended in autumn 2008 at both sites. Each crop of each rotation was grown in each year, according to the principles of crop rotation experiment, to allow for the analysis of year by crop interaction. Sowing dates of the crops depended on the cropping systems and are indicated in Figure 1 by thin vertical lines. Nitrogen fertilizer was given at four supply levels, denoted as N1, N2, N3, and N4. For maize and wheat this was $0,120,180$, and $360 \mathrm{~kg} \mathrm{~N} \mathrm{ha}^{-1}$, split for maize into two and for wheat into three equal amounts. Nitrogen fertilization levels for the perennial ryegrass were $0,160,320$, and $480 \mathrm{~kg} \mathrm{~N} \mathrm{ha}^{-1}$, split into four applications, one for each cut with decreasing rates. Only two different $\mathrm{N}$ levels were distinguished for the Italian ryegrass winter cover crop: N1 $\left(0 \mathrm{~kg} \mathrm{~N} \mathrm{ha}^{-1}\right)$ and $\mathrm{N} 2, \mathrm{~N} 3, \mathrm{~N} 4$ (each $160 \mathrm{~kg} \mathrm{~N} \mathrm{ha}^{-1}$ ), split into two equal rates in early autumn and early spring. The catch crop of CS3 was not fertilized. Nitrogen fertilizer was applied as calcium ammonium nitrate. All other crop management-e.g., pest and disease control—was based on local best-practice recommendations. Additional information about the experimental layout is presented in $[15,16]$.

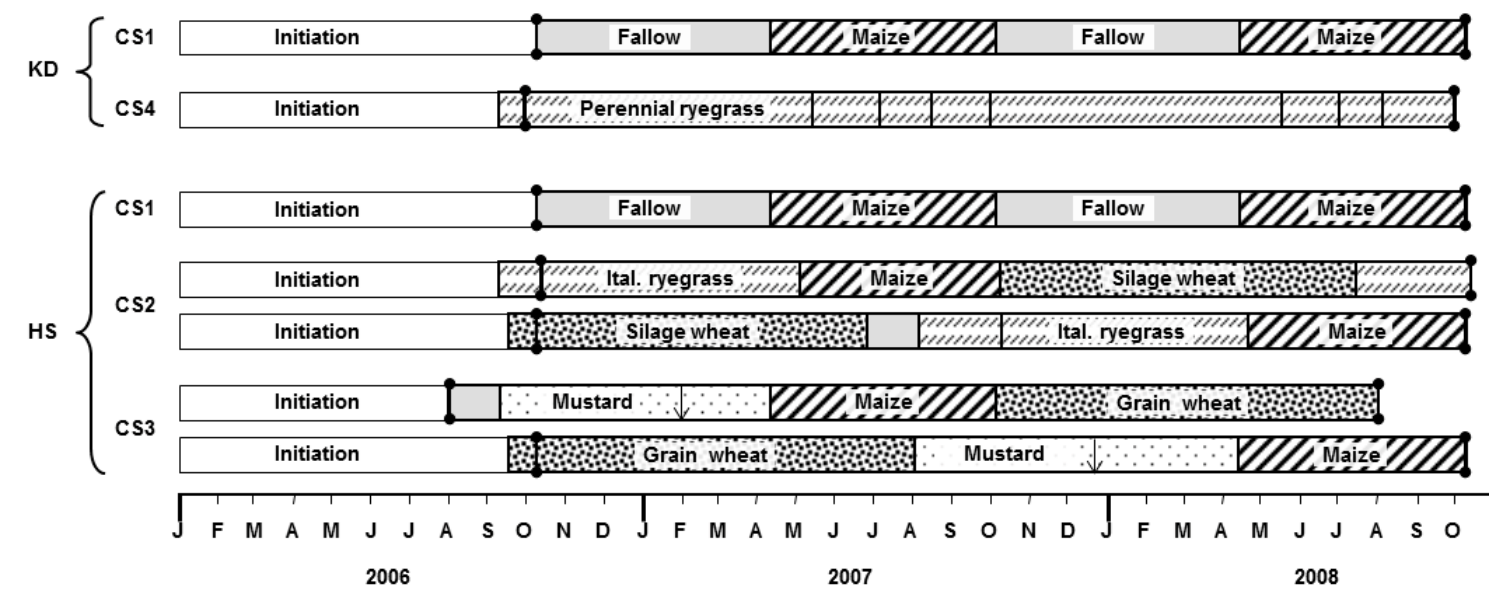

Figure 1. Cropping systems of the field trial in Hohenschulen (HS) and Karkendamm (KD). Thin vertical lines indicate sowing or harvest cutting dates respectively. If the interval between harvesting and sowing of the following crop was $<14$ days, sowing date was not additionally shown. Arrows indicate the freezing-off date of the catch crop, used as the harvest date. Thick vertical lines with dots show start and end of the period, which was considered by quantification via modelling (24 months). 'Initiation' indicates the model calculation period conducted in advanced to level off some output variables, e.g., soil water contents. 


\subsubsection{Measurement State Variables}

Above-ground dry matter (DM yield) $\left(\mathrm{Mg} \mathrm{ha}^{-1}\right)$, above-ground $\mathrm{N}$ uptake $\left(\mathrm{kg} \mathrm{ha}^{-1}\right)$, crop height $(\mathrm{cm})$ and green area index $\left(\mathrm{m}^{2} \mathrm{~m}^{-2}\right)(\mathrm{GAI})$ were determined as crop state variables. DM yield and $\mathrm{N}$ uptake were obtained by mechanical harvest. Thereby fresh matter per unit area was measured by the harvester's internal weighing system and corrected to DM yield based on the DM content of a subsample. The same subsamples were also used for determining $\mathrm{N}$ concentration by near-infrared-spectroscopy (FOSS NIR Systems Modell 5000). Crop height and GAI were measured during the whole growth period at an approximately fortnightly interval. The measurements for the catch crop were carried out at five measurement dates during the growth period of 2008. Early stage measurements of GAI were conducted by taking digital pictures, from which ground cover values were estimated by a digital image analysis technique [21]. Ground cover then was transformed into GAI values using the Lambert-Beer law. As soon as GAI values were > 1, the LAI-2000 (LI-COR LAI-2000 m; LI-COR, Inc., Lincoln, NE, USA) was used for determining GAI.

For maize (10 plants) and wheat $\left(0.25 \mathrm{~m}^{2}\right)$ additional 'destructive' samples were taken at every second measurement date. Plants were fractionated into leaf, stem and generative organs. Leaf and stem area were routinely measured using the LAI-3100 (LI-COR, Inc., Lincoln, NE, USA). These destructively measured GAI values were used to adjust the LAI-2000 GAI values by crop-specific linear regressions without intercept, resulting in transformation factor values of 1.22 for maize and 1.14 for wheat. LAI-2000 data obtained in the grass crops and in the catch crop were also transformed by 1.14. In all crops, crop height was determined in the N1 and N4 plots only. Missing crop height values were deduced from best fit regression correlations between measured GAI and crop height values, assuming for all crops that crop height stayed constant with decreasing GAI.

In order to close the data gaps for the catch crop (mustard), a dynamic plant growth model for oilseed rape described by [22] was used. The required specific parameterization for mustard was mostly derived from an unpublished mustard data set of a field trial conducted in autumn of 1998 at a site located near Hannover, Germany. The calibrated growth model for mustard was validated against above-ground DM data gained within the described field trial at HS in 2006, 2007, and 2008 at the end of the growth period and resulted in a RMSE of $34 \mathrm{~g} \mathrm{~m}^{-2}$. Validation of the model concerning GAI was conducted using the GAI time course data observed during autumn and winter 2007/2008 in HS and resulted in an RMSE of $0.92 \mathrm{~m}^{2} \mathrm{~m}^{-2}$. Finally, this plant growth model for mustard was used to calculate the missing DM yield values at the freezing-off date and the missing GAI values over the growth period.

Soil water content was measured using the time domain reflectometry (TDR) technique [23] at $30 \mathrm{~cm}$ layers down to $120 \mathrm{~cm}$, which were recorded at the same time as the fortnightly measurements. For the same soil layers, but just to $90 \mathrm{~cm}$ soil depth, soil samples for determining gravimetric soil water content and mineral soil $\mathrm{N}$ content (SMN) were taken at sowing, at the end of autumn growth, at the start of spring growth and at harvest. At site KD the groundwater table was measured weekly at six dipwells using a water level meter.

\subsubsection{Statistics}

For both, the above-ground DM accumulated over a whole cropping system and above-ground DM of single crops, single block values averaged over the two years were used for the statistical analyses. Data were subjected to an analysis of variance using the SAS procedure PROC MIXED, with block set as random (SAS version 8.2, SAS Institute Inc., Cary, NC, USA). Comparison of means was performed by the Tukey test.

\subsection{Model Based Calculations}

A simple model approach was used to calculate photosynthetically active radiation interception $(\mathrm{Q})$, temperature and drought stress effects, drainage, transpiration $\left(\mathrm{TI}_{\mathrm{act}}\right)$, and evaporation $\left(\mathrm{E}_{\mathrm{act}}\right)$ for 
the different cropping systems. Light use efficiency (LUE), transpiration use efficiency (TUE) and evapotranspiration use efficiency (WUE) values were calculated from the measured above-ground DM at harvest and corresponding modelled cumulative values of $\mathrm{Q}, \mathrm{TI}_{\mathrm{act}}$ and $\mathrm{E}_{\mathrm{act}}$. In order to assure the comparability of the results the time span analyzed was exactly two years (see vertical lines with dots in Figure 1), ending for each cropping system with the harvest date of the last crop in 2008. Based on this reference date, starting dates of the quantification periods differ slightly for the cropping systems and do not start exactly with the sowing date of the first crop in 2006.

\subsubsection{General Concept}

The model approach is comparable to the approach described in [17] and [24]. Measured crop state variables were linearly interpolated and used as inputs for the evapotranspiration and soil water model. Root growth was modelled according to [25]. Potential evapotranspiration and soil water balance are calculated following a mechanistic modelling approach [26]. The model is implemented using an object-orientated component library [27]. Principally, the model runs on daily time steps, just internal processes of the soil water balance module are calculated by a variable length of time steps.

\subsubsection{Evapotranspiration Module}

Potential evapotranspiration $\left(\mathrm{mm} \mathrm{d}^{-1}\right)\left(\mathrm{ET}_{\mathrm{pot}}\right)$ is calculated using the Penman-Monteith equation [28]. For calculating the canopy resistance $\left(\mathrm{s} \mathrm{m}^{-1}\right)(\mathrm{rc})$ and the aerodynamic resistance $\left(\mathrm{s} \mathrm{m}^{-1}\right)$ (ra), weather data, GAI and crop height are needed as input variables. Important crop-dependent parameters are $\mathrm{rc} 0\left(\mathrm{~s} \mathrm{~m}^{-1}\right)$, canopy resistance at optimum water supply, and $\mathrm{k}_{\text {glob }}(-)$, the extinction coefficient for global solar radiation (Table 2). The value $\mathrm{k}_{\text {glob }}$ was derived from the extinction coefficient for photosynthetic active radiation (PAR) by a division factor of 1.35 [29].

Table 2. Crop parameters, their units and values, as used in the model analysis.

\begin{tabular}{|c|c|c|c|c|c|}
\hline \multirow[t]{2}{*}{ Parameter } & \multirow[t]{2}{*}{ Dimension } & \multicolumn{4}{|c|}{ Crop } \\
\hline & & Maize & Wheat & Grass & Catch Crop \\
\hline $\mathrm{rc0}$ & $\mathrm{s} \mathrm{m}^{-1}$ & 75 & 50 & 50 & 50 \\
\hline $\mathrm{T}_{1}$ & ${ }^{\circ} \mathrm{C}$ & 6 & 0 & 0 & 3 \\
\hline $\mathrm{T}_{2}$ & ${ }^{\circ} \mathrm{C}$ & 16 & 10 & 10 & 10 \\
\hline $\mathrm{T}_{3}$ & ${ }^{\circ} \mathrm{C}$ & 28 & 20 & 20 & 20 \\
\hline $\mathrm{T}_{4}$ & ${ }^{\circ} \mathrm{C}$ & 34 & 34 & 34 & 34 \\
\hline $\mathrm{GDD}_{\text {emer }}$ & ${ }^{\circ} \mathrm{C} \mathrm{d}$ & 77.5 & 168 & 124 & 150 \\
\hline $\mathrm{k}_{\mathrm{PAR}}$ & - & 0.661 & 0.5 & $0.63^{+}, 0.55^{++}$ & 0.85 \\
\hline $\mathrm{zr}_{0}$ & $\mathrm{Cm}$ & 6 & 2 & $1^{\#}$ & 2 \\
\hline $\mathrm{zr}_{\max }$ & $\mathrm{Cm}$ & 100 & 120 & 70 & 120 \\
\hline $\mathrm{k}_{\mathrm{zr}}$ & $\mathrm{cm}\left({ }^{\circ} \mathrm{Cd}\right)^{-1}$ & 0.156 & 0.09 & 0.09 & 0.09 \\
\hline $\mathrm{RL}_{0}$ & $\mathrm{~cm} \mathrm{~cm}^{-2}$ & 3.7 & 1 & $1^{\#}$ & 1 \\
\hline $\mathrm{RL}_{\max }$ & $\mathrm{cm} \mathrm{cm}^{-2}$ & 252 & 300 & 300 & 80 \\
\hline $\mathrm{k}_{\mathrm{RL}}$ & $\mathrm{cm} \mathrm{cm}^{-2}\left({ }^{\circ} \mathrm{C} \mathrm{d}\right)^{-1}$ & 0.0087 & 0.0045 & 0.0045 & 0.0045 \\
\hline $\mathrm{k}_{\mathrm{a}}$ & {$[-]$} & 0.009 & 0.042 & 0.042 & 0.042 \\
\hline psi $_{\text {crit }}$ & $\mathrm{hPa}$ & 439 & 200 & 500 & 500 \\
\hline
\end{tabular}

${ }^{+}:$Italian ryegrass, ${ }^{++}$: Perennial ryegrass; ${ }^{\#}$ : Parameter values, used for simulating crop establishment.

\subsubsection{Soil Water}

The soil water balance module is essentially the same as described in [26]. The soil profile is subdivided into a number of layers, for which vertical soil water movement is calculated using the water content-based formulation of the Richards equation. The retention function proposed by [30] in the formulation revised by [31] thereby is used. Potential transpiration is distributed between the soil layers depending on root length densities. The actual water uptake in each layer is calculated 
by a reduction factor according to [32], using a crop-specific critical soil water potential (hPa) $\left(\mathrm{psi}_{\text {crit }}\right)$ (Table 2). Actual evaporation ( $\left.\mathrm{mm} \mathrm{d}^{-1}\right)\left(\mathrm{E}_{\mathrm{act}}\right)$ is calculated by a reduction factor, which corrects $\mathrm{E}_{\mathrm{pot}}$ by the influence of low soil water content in the top soil layer, according to a critical soil water potential

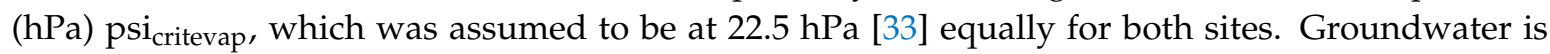
considered by measured values of the groundwater table, which represent then the lower boundary condition for the Richards equation. The van Genuchten parameters and the saturated soil conductivity for the two different sites are given in Table 3.

Table 3. Soil texture, van Genuchten parameter considering Mualem parameterization $(\alpha, \theta \mathrm{s}, \theta \mathrm{r}$, and $\mathrm{n})$ and saturated water conductivity (KS) for Hohenschulen (HS) and Karkendamm (KD) subdivided in the different soil horizons [cm]. If not extra assigned, parameter values result from direct measurements at the soil pits dug at the two sites.

\begin{tabular}{|c|c|c|c|c|c|c|c|}
\hline Site & Soil Horizn & Soil Texture & $\alpha\left(\mathrm{cm}^{-1}\right)$ & $\Theta s\left(\mathrm{~cm}^{3} \mathrm{~cm}^{-3}\right)$ & $\Theta r\left(\mathrm{~cm}^{3} \mathrm{~cm}^{-3}\right)$ & $\mathbf{N}(-)$ & $\mathrm{KS}\left(\mathrm{cm} \mathrm{d}^{-1}\right)$ \\
\hline \multirow{4}{*}{ HS } & $0-30$ & \multirow{4}{*}{ S14 } & \multirow{4}{*}{$0.043^{+}$} & \multirow{4}{*}{$0.3394^{+}$} & \multirow{4}{*}{$0^{+}$} & \multirow{4}{*}{$1.18^{+}$} & \\
\hline & $30-60$ & & & & & & $42^{+}$ \\
\hline & $60-90$ & & & & & & \\
\hline & 90-200 & & & & & & $21^{+}$ \\
\hline \multirow{4}{*}{ KD } & $0-30$ & $\mathrm{mSgs}$ & 0.038 & 0.4276 & 0.1187 & 1.66 & 41 \\
\hline & $30-40$ & $\mathrm{mSfs}$ & 0.035 & 0.3661 & 0.0783 & 2.48 & 91 \\
\hline & $40-50$ & mSgs & 0.042 & 0.4008 & 0.1375 & 1.62 & 157 \\
\hline & $50-200$ & SS & $0.087^{+}$ & $0.3707^{+}$ & $0.0430^{+}$ & $1.57^{+}$ & $67^{+}$ \\
\hline
\end{tabular}

${ }^{+}$: Parameter values are derived from [34].

\subsubsection{Crop Growth}

GAI and crop height data are linearly interpolated by the model, starting with emergence which is calculated by a crop-specific temperature sum $\left({ }^{\circ} \mathrm{C} d\right)\left(G_{\text {DDemer }}\right)$ (Table 2). An empirical dynamic model approach is used to calculate root growth [25]. Rooting depth $\mathrm{zr}(\mathrm{cm})$ thereby increases linearly with effective temperature, for which the parameter $\mathrm{k}_{\mathrm{zr}}\left(\mathrm{cm}\left({ }^{\circ} \mathrm{C} \mathrm{d}\right)^{-1}\right)$ denotes the increase of rooting depth per growing degree day. Rooting depth increase stops if a maximum predefined rooting depth $\mathrm{zr}_{\max }$ $(\mathrm{cm})$ is reached. Root length $\mathrm{RL}\left(\mathrm{cm} \mathrm{cm}^{-2}\right)$ is assumed to be a logistic function of temperature sum, using parameters describing the initial $\left(\mathrm{RL}_{0}\right)$ and maximal root length per unit soil $\left(\mathrm{RL}_{\max }\left(\mathrm{cm} \mathrm{cm}^{-2}\right)\right)$ and using $\mathrm{k}_{\mathrm{RL}}\left(\mathrm{cm} \mathrm{cm}^{-2}\left({ }^{\circ} \mathrm{C} \mathrm{d}\right)^{-1}\right)$, a growth rate parameter (Table 2). The vertical root distribution is calculated by an exponential decrease of root length density RLD $\left(\mathrm{cm} \mathrm{cm}^{-3}\right)$ with soil depth $(\mathrm{z})$ $(\mathrm{cm})$. Thereby, $\mathrm{k}_{\mathrm{r}}$, the fractional decrease in RLD per increasing soil depth, is calculated as the negative logarithm of a fit parameter $\mathrm{k}_{\mathrm{a}}(-)$ (Table 2) divided by $\mathrm{zr}$.

PAR interception $(Q)$ is calculated by incident PAR, GAI and the extinction coefficient for PAR $\left(\mathrm{k}_{\mathrm{PAR}}\right)(-)$ (Equation (1)).

$$
\mathrm{Q}=\operatorname{PAR}\left(1-\mathrm{e}^{-\mathrm{k}_{\mathrm{PAR}} \cdot \mathrm{GAI}}\right)
$$

Thereby, PAR is derived from the global radiation using a factor of 0.5 according to [35]. The $\mathrm{k}_{\text {PAR }}$ is assumed to be constant and to include effects of canopy reflection. The crop specific $k_{\text {PAR }}$ value for maize was calculated from the GAI data and the measured fraction of non-intercepted diffuse radiation (DIFN data) measured by the LAI-2000 device, according to [36]. For wheat, $\mathrm{k}_{\mathrm{PAR}}$ was taken from [37], for mustard a $k_{P A R}$ value of oilseed rape was taken from [38] assuming that it is also valid for mustard, for Italian ryegrass a value from [39] and for perennial ryegrass from [39] and [40] were taken (Table 2).

The temperature factor $\left(\mathrm{f}_{\mathrm{T}}\right)(-)$ is calculated by the crop-specific cardinal temperatures $\mathrm{T}_{1}, \mathrm{~T}_{2}, \mathrm{~T}_{3}$, and $\mathrm{T}_{4}\left[{ }^{\circ} \mathrm{C}\right]$ (Table 2), describing a trapezoid optimum function. The drought stress factor (SWDF) (-), varying between 0 and 1 , is calculated by the ratio between $T_{\text {act }}$ and $T_{\text {pot }}$. In this study, $\mathrm{f}_{\mathrm{T}}$ and SWDF were weighted by the daily PAR interception before calculating mean values for each cropping system, 
in order to account for the stress impact on DM production. A more detailed description of some of the modelling approaches and equations used is given by [41].

\subsubsection{Statistical Measures}

The performance of the soil water model was tested concerning the soil water balance by comparing simulated with measured values of volumetric soil water content. Coefficient of correlation $\left(r^{2}\right)$ as well as slope and intercept including standard errors (SE) of the linear regression $(y=a+b x)$ between the measured and simulated values, root mean square error (RMSE), coefficient of determination (CD) and modelling efficiency (EF) [42] have been determined.

\section{Results}

\subsection{Dry Matter Yield}

Under sufficient $\mathrm{N}$ supply (N3) the three cropping systems at HS showed small but not significant differences of DM yield averaged over the two years ( $p$-value 0.647) (Figure 2). At KD, CS1 (maize-maize) yielded significantly higher than CS4 (perennial ryegrass) (N3).

However, including all N levels at both sites, cropping systems' DM yields differed significantly, with CS1 as the most productive system. Also the interaction CS $\times \mathrm{N}$ was significant for both sites (Table 4) depicting the fact that CS1 achieved higher DM yields especially under low N. At HS, DM yield of CS2 significantly increased with increasing $\mathrm{N}$ supply up to $240 \mathrm{~kg} \mathrm{~N}^{-1}$, whereas in CS1 and CS3, an N effect was only observed from N1 to N2 (0 to $\left.120 \mathrm{~kg} \mathrm{~N} \mathrm{ha}^{-1}\right)$. At HS, no DM yield increase occurred with $\mathrm{N}$ supply exceeded $240 \mathrm{~kg} \mathrm{~N}$ ha $^{-1}$ for any of the cropping systems. In CS4 at KD, DM yield increases if $\mathrm{N}$ supply ranged between 0 and $320 \mathrm{~kg} \mathrm{~N} \mathrm{ha}^{-1}$, whereas CS1 showed an effect only from N1 to N2 (0 to $\left.120 \mathrm{~kg} \mathrm{~N} \mathrm{ha}^{-1}\right)$. At KD, neither of the cropping systems achieved higher DM yields under the N supply of N4 as compared to N3. CS1 at HS outyielded CS1 at KD, without a significant site $\mathrm{x}$ interaction.

Table 4. $p$-values of the main effects and interactions on the whole cropping system dry matter yields.

\begin{tabular}{cccc}
\hline Site & Cropping System & Factors & $p$-Value \\
\hline \multirow{3}{*}{$\mathrm{HS}$} & $\mathrm{CS} 1, \mathrm{CS} 2, \mathrm{CS} 3$ & $\mathrm{~N}$ & $<0.0001$ \\
& & $\mathrm{CS}$ & $<0.0001$ \\
& $\mathrm{CS} \times \mathrm{N}$ & 0.0024 \\
\hline \multirow{2}{*}{$\mathrm{KD}$} & $\mathrm{CS} 1, \mathrm{CS} 4$ & $\mathrm{~N}$ & $<0.0001$ \\
& & $\mathrm{CS}$ & $<0.0001$ \\
& & $\mathrm{CS} \times \mathrm{N}$ & 0.0309 \\
\hline \multirow{2}{*}{$\mathrm{HS}+\mathrm{KD}$} & $\mathrm{N}$ & $<0.0001$ \\
& \multirow{2}{*}{$\mathrm{CS} 1$} & site & 0.0008 \\
& & site x N & 0.3235 \\
\hline
\end{tabular}

Within the cropping systems CS2 and CS3, maize achieved higher DM yields compared to wheat (Figure 2). Italian ryegrass grown as a winter cover crop produced more above-ground biomass than the catch crop mustard. The effect of N supply on DM yields of the single crop was species dependent and differed for maize and wheat between the cropping systems. Maize in CS3 showed no DM yield response to an increasing N supply, whereas maize in CS1 (HS and KD) showed an increase from $\mathrm{N} 1$ to N2, and maize grown CS2 from N1 up to N3. Wheat in CS2 yielded higher with an N supply increasing from N1 to N3, whereas DM yield of wheat in CS3 only increased from N1 to N2.

At HS, cropping systems' DM yield differed between the two years. For CS1, DM yields were similar in both years, whereas those of CS2 and CS3 were higher in 2008. Thereby, yield differences for wheat between both years were more distinct than for maize. 


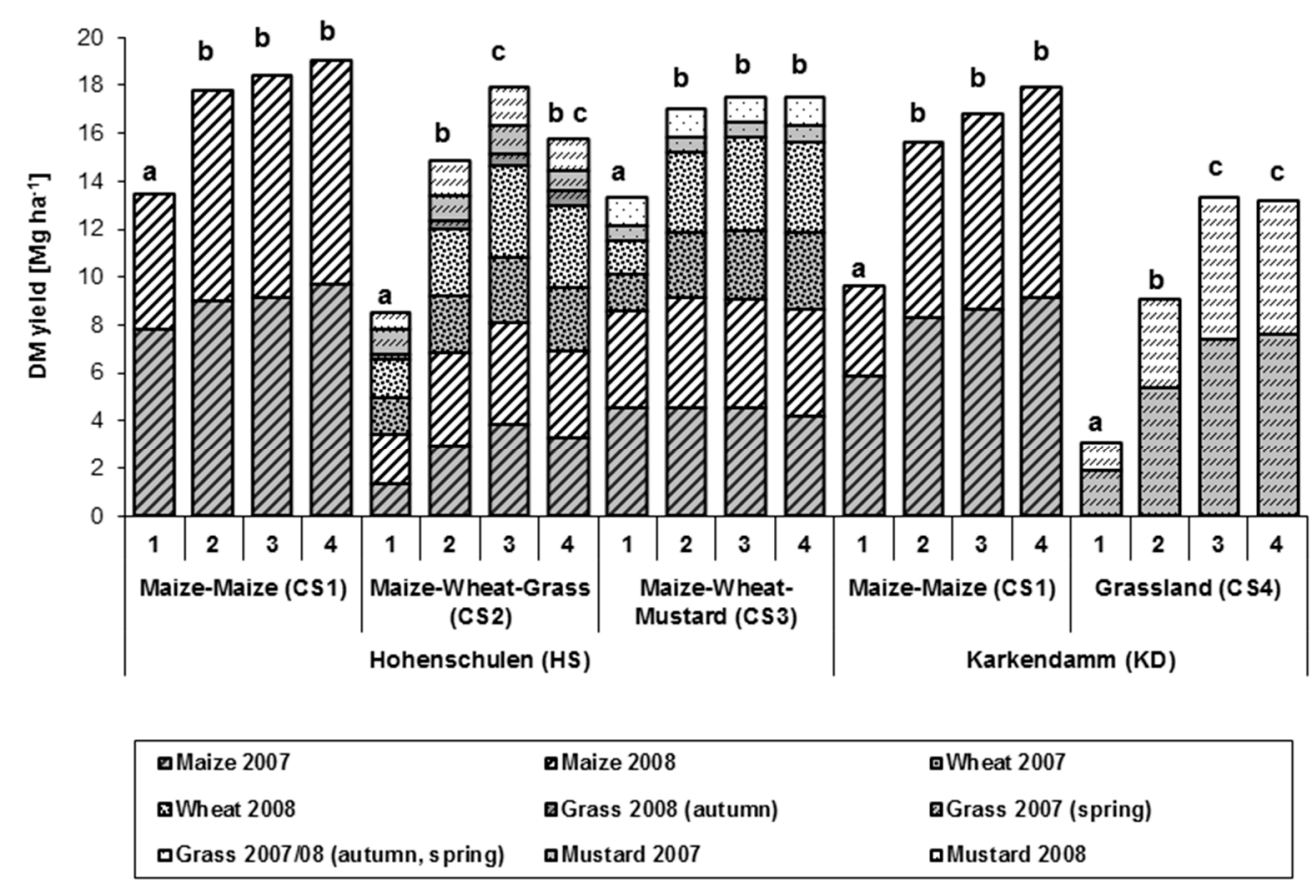

Figure 2. Dry matter (DM) yields of the different cropping systems averaged per year, indicated by the total height of each bar and given separately for the different $\mathrm{N}$ levels (1-4). Different signatures indicate different crops. Different colors indicate the yield proportion of the crop in each experimental year. The sum of the sub-bars with the same hatching but with different colors indicates the mean DM yield per year of each crop within a cropping system. Significant differences $(p<0.05)$ between the different $\mathrm{N}$ treatments within a cropping system are indicated by different letters (' $a$ ' to ' $c$ ').

\subsection{Radiation Interception, Light-Use Efficiency, Stress Factors}

Both crop rotations with winter crops, CS2 and CS3, intercepted high portions of radiation during longer periods than CS1, although low incident PAR occurred during autumn and winter, as derived from the temporal dynamics of incident PAR and of the proportion of PAR interception (Figure 3). PAR interception of CS1 is restricted to a comparatively short period (late spring till autumn), leaving considerable amounts of potential PAR in spring unused. In total, this led to the lowest accumulated PAR interception $(\Sigma \mathrm{Q})$ by CS1, followed by CS3, and to highest $\Sigma$ Q by CS2 (Table 5). At KD, $\Sigma Q$ of CS4 clearly exceeded that of CS1 (Table 5), despite its low above-ground DM yield (Figure 2). The observed PAR interception of the cropping systems is not correlated with their DM yield. CS4 clearly showed the lowest LUE values of all cropping systems. LUE of CS1 was higher at $\mathrm{HS}$ than at KD, whereas $\Sigma \mathrm{Q}$ differed just slightly. Average LUE values ranked opposite to those of $\Sigma Q$ with the highest values for CS1 and lowest for the grass swards (CS4) (Table 5).

The cropping systems differed in their response of PAR interception and light use efficiency to $\mathrm{N}$ supply, with larger increases of PAR interception due to higher N supply in CS2, CS3 and the grass systems and somewhat higher effects on LUE in CS1, especially at the KD site. These differences are caused by the differences between the crops they consist of and cropping system effects (Figure 4). In general, maize had a higher LUE than the $\mathrm{C} 3$ crops wheat and grass, but the $\mathrm{N}$ effect on the maize crops differed between the cropping systems (Figure 4). Especially in CS3 where a catch crop was grown before maize, the $\mathrm{N}$ effect on LUE and PAR interception was negligible. Radiation interception of wheat and grass was more sensitive to increasing $\mathrm{N}$ supply than it was for maize but tended to be more stable in LUE than maize in CS2 and CS3. 

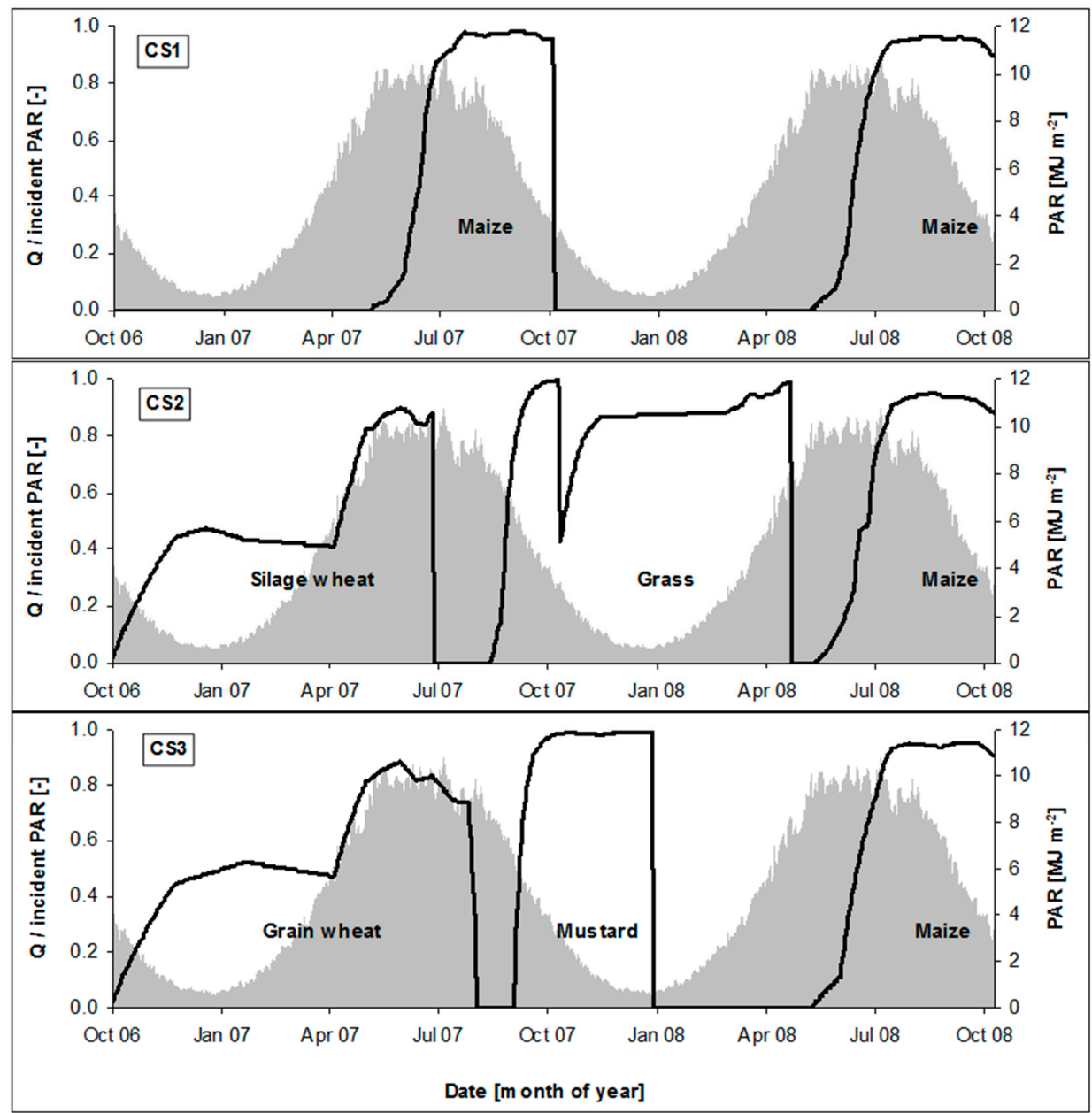

Figure 3. Simulated time courses of the ratio between absorbed and incident PAR (Q/incident PAR) for the three cropping systems cultivated in Hohenschulen (HS) at the N3 treatment (black lines) and a 35-years averaged time course of PAR measured at HS (gray).

Table 5. Photosynthetic active radiation (PAR) interception (MJ m ${ }^{-2} \mathrm{a}^{-1}$ ) and light use efficiency $\left(\mathrm{g} \mathrm{MJ}^{-1}\right.$ ) of cropping systems in Hohenschulen (HS) and Karkendamm (KD), separated between N-levels.

\begin{tabular}{|c|c|c|c|c|c|c|}
\hline \multirow[t]{3}{*}{ Site } & \multirow[t]{3}{*}{ Cropping System } & \multicolumn{5}{|c|}{ PAR Interception (MJ $\left.\mathrm{m}^{-2} \mathrm{a}^{-1}\right)$} \\
\hline & & \multicolumn{4}{|c|}{ N-Level } & \\
\hline & & 1 & 2 & 3 & 4 & Mean \\
\hline \multirow{3}{*}{ HS } & 1 & 713 & 741 & 747 & 748 & 737 \\
\hline & 2 & 826 & 999 & 1046 & 1041 & 978 \\
\hline & 3 & 770 & 901 & 905 & 921 & 874 \\
\hline \multirow{3}{*}{$\mathrm{KD}$} & 1 & 690 & 769 & 761 & 763 & 746 \\
\hline & 4 & 998 & 1340 & 1434 & 1449 & 1305 \\
\hline & & \multicolumn{5}{|c|}{ Light Use Efficiency (MJ.m $\left.{ }^{-2} \cdot a^{-1}\right)$} \\
\hline \multirow{3}{*}{ HS } & 1 & 1.9 & 2.4 & 2.5 & 2.5 & 2.3 \\
\hline & 2 & 1.0 & 1.5 & 1.7 & 1.5 & 1.4 \\
\hline & 3 & 1.7 & 1.9 & 1.9 & 1.9 & 1.9 \\
\hline \multirow{2}{*}{ KD } & 1 & 1.4 & 2.0 & 2.2 & 2.3 & 2.0 \\
\hline & 4 & 0.3 & 0.7 & 0.9 & 0.9 & 0.7 \\
\hline
\end{tabular}


Reported $\Sigma \mathrm{Q}$ and LUE values (Table 5) were affected by calculated drought (SWDF) and temperature stress $\left(\mathrm{f}_{\mathrm{T}}\right)$ factors (Table 6). At HS, SWDF and $\mathrm{f}_{\mathrm{T}}$ did not differ strongly between the cropping systems. Nevertheless, at high N supply the lowest drought stress impact occurred in CS1, as indicated by highest SWDF values, whereas the lowest impact of suboptimal temperatures was observed in CS3, as indicated by the highest $\mathrm{f}_{\mathrm{T}}$ values. At KD, CS4 (grass sward) was clearly exposed to a higher drought stress compared to CS1, whereas no differences concerning $\mathrm{f}_{\mathrm{T}}$ were observed between CS4 and CS1. Without N supply, all cropping systems showed slightly lower drought stress than with $\mathrm{N}$ supply. As expected, $\mathrm{N}$ supply level did not affect the temperature stress factor $\mathrm{f}_{\mathrm{T}}$ in all cropping systems.

Table 6. Calculated drought stress factor (SWDF) and temperature stress factor $\mathrm{f}_{\mathrm{T}}$ of all crops and cropping systems in Hohenschulen (HS) and Karkendamm (KD), separated between cropping systems (CS) and N-levels. Only SWDF is given separately for the different N-Levels because $\mathrm{f}_{\mathrm{T}}$ was not influenced by $\mathrm{N}$ supply. $\mathrm{f}_{\mathrm{T}}$ and SWDF were, before averaging, weighted by the daily PAR absorption. High values indicate low stress impact. Means of a crop rotation is given in bold.

\begin{tabular}{cccccccc}
\hline Site & Crop/System & \multicolumn{7}{c}{ SWDF } \\
\hline & $\mathbf{1}$ & $\mathbf{2}$ & $\mathbf{3}$ & $\mathbf{4}$ & Mean \\
\hline & Maize CS1 & $\mathbf{0 . 9 5}$ & $\mathbf{0 . 9 2}$ & $\mathbf{0 . 9 0}$ & $\mathbf{0 . 9 1}$ & $\mathbf{0 . 9 2}$ & $\mathbf{0 . 8 8}$ \\
& Maize CS2 & 1.00 & 0.96 & 0.95 & 0.96 & 0.97 & 0.87 \\
& Wheat CS2 & 0.89 & 0.81 & 0.78 & 0.77 & 0.81 & 0.93 \\
& Grass Intercrop CS2 & 0.96 & 0.95 & 0.95 & 0.95 & 0.95 & 0.78 \\
& CS 2 & $\mathbf{0 . 9 4}$ & $\mathbf{0 . 8 9}$ & $\mathbf{0 . 8 8}$ & $\mathbf{0 . 8 8}$ & $\mathbf{0 . 9 2}$ & $\mathbf{0 . 8 6}$ \\
HS & Maize CS3 & 0.93 & 0.90 & 0.91 & 0.92 & 0.92 & 0.88 \\
& Wheat CS3 & 0.90 & 0.81 & 0.80 & 0.78 & 0.82 & 0.94 \\
& Mustard CS3 & 1.00 & 1.00 & 1.00 & 1.00 & 1.00 & 0.73 \\
& CS 3 & $\mathbf{0 . 9 3}$ & $\mathbf{0 . 8 7}$ & $\mathbf{0 . 8 6}$ & $\mathbf{0 . 8 6}$ & $\mathbf{0 . 9 1}$ & $\mathbf{0 . 8 5}$ \\
\hline \multirow{2}{*}{ KD } & Maize CS1 & $\mathbf{0 . 9 3}$ & $\mathbf{0 . 9 0}$ & $\mathbf{0 . 9 0}$ & $\mathbf{0 . 9 0}$ & $\mathbf{0 . 9 0}$ & $\mathbf{0 . 9 0}$ \\
& Grass CS4 & $\mathbf{0 . 8 4}$ & $\mathbf{0 . 8 0}$ & $\mathbf{0 . 8 0}$ & $\mathbf{0 . 8 0}$ & $\mathbf{0 . 8 1}$ & $\mathbf{0 . 9 0}$ \\
\hline
\end{tabular}
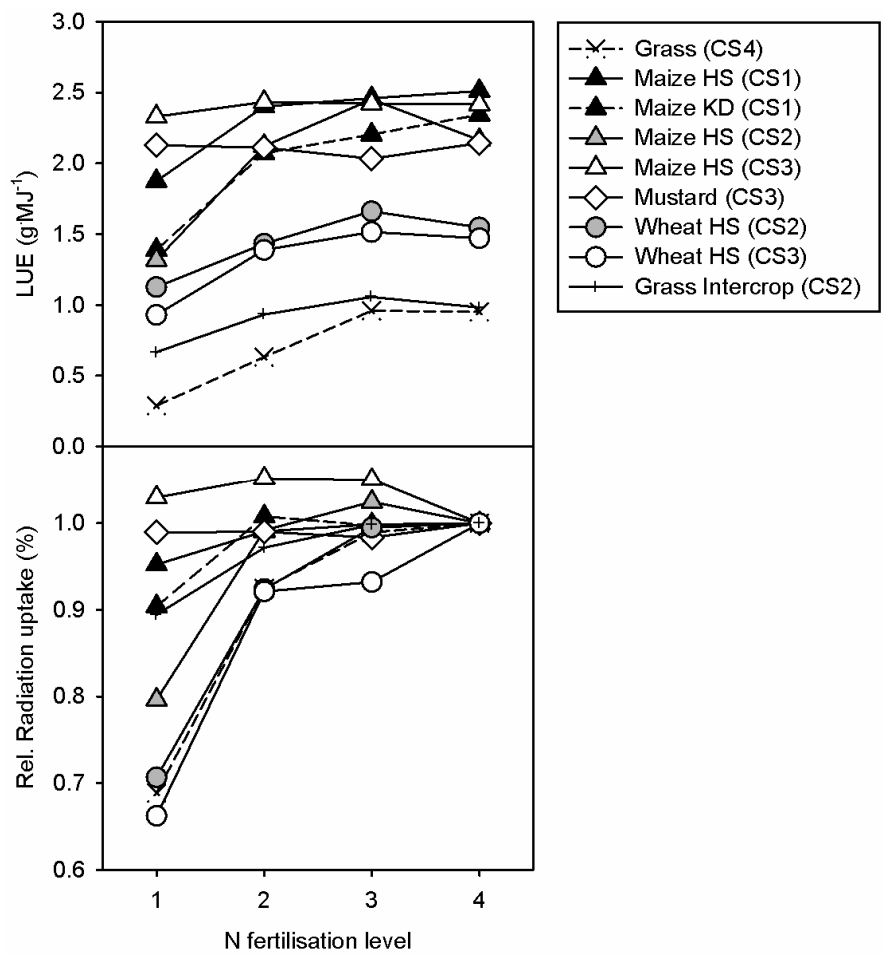

Figure 4. Light use efficiency (LUE) $\left(\mathrm{g} \mathrm{MJ}^{-1}\right.$ ) and relative radiation uptake (\%) for the crops of the different cropping systems as a function of the $\mathrm{N}$ fertilization level of the cropping systems (CS1-CS4) cultivated at Hohenschulen (HS) and Karkendamm (KD). 


\subsection{Water Balance and Water-Use Efficiencies}

The approximately fortnightly-measured soil water content data for 0-90 cm (mean values of replications) $\left(\mathrm{cm}^{3} \mathrm{~cm}^{-3}\right)$ were used to evaluate the model performance in terms of soil water balance. At both sites the $r^{2}$ value of 0.75 and the RMSE of $0.025 \mathrm{~cm}^{3} \mathrm{~cm}^{-3}$ indicate an adequate model performance (Table 7). The chosen examples of time courses of simulated and measured soil water contents (HS CS3 N4 2008 and KD CS1 N4 2008, Figure 5) revealed some considerable differences between the two sites. At HS, the variability of the soil water content dynamic over time was much higher compared to the variability observed within one measurement date. In contrast, at $\mathrm{KD}$, a generally high variability of the soil water content data within one measurement date occurred, accompanied by a generally low variability of the whole soil water content dynamic over time, which had to be considered. This lower variability of the soil water dynamic over time results in the lower accuracy for modelling the dynamics for KD compared to HS (Table 7).

Table 7. Model performance for soil water contents in the soil layer from 0-90 cm calculated for all data $(\mathrm{HS}+\mathrm{KD}$ ) of the field experiment and separately for each site (Hohenschulen (HS) and Karkendamm (KD)). Statistical parameters are slope, intercept and their SEs and $r^{2}$ of the linear regression between the measured and simulated results, RMSE, EF, CD, and n.

\begin{tabular}{cccccccc}
\hline Site & Slope (SE) & Intercept (SE) & $\boldsymbol{r}^{\mathbf{2}}$ & RMSE & EF & CD & $\mathbf{n}$ \\
\hline HS + KD & $0.84( \pm 0.035)$ & $0.037( \pm 0.009)$ & 0.75 & 0.025 & 0.72 & 0.94 & 187 \\
HS & $0.68( \pm 0.047)$ & $0.085( \pm 0.013)$ & 0.62 & 0.026 & 0.47 & 0.75 & 131 \\
KD & $0.56( \pm 0.076)$ & $0.080( \pm 0.015)$ & 0.51 & 0.022 & 0.08 & 0.58 & 56 \\
\hline
\end{tabular}

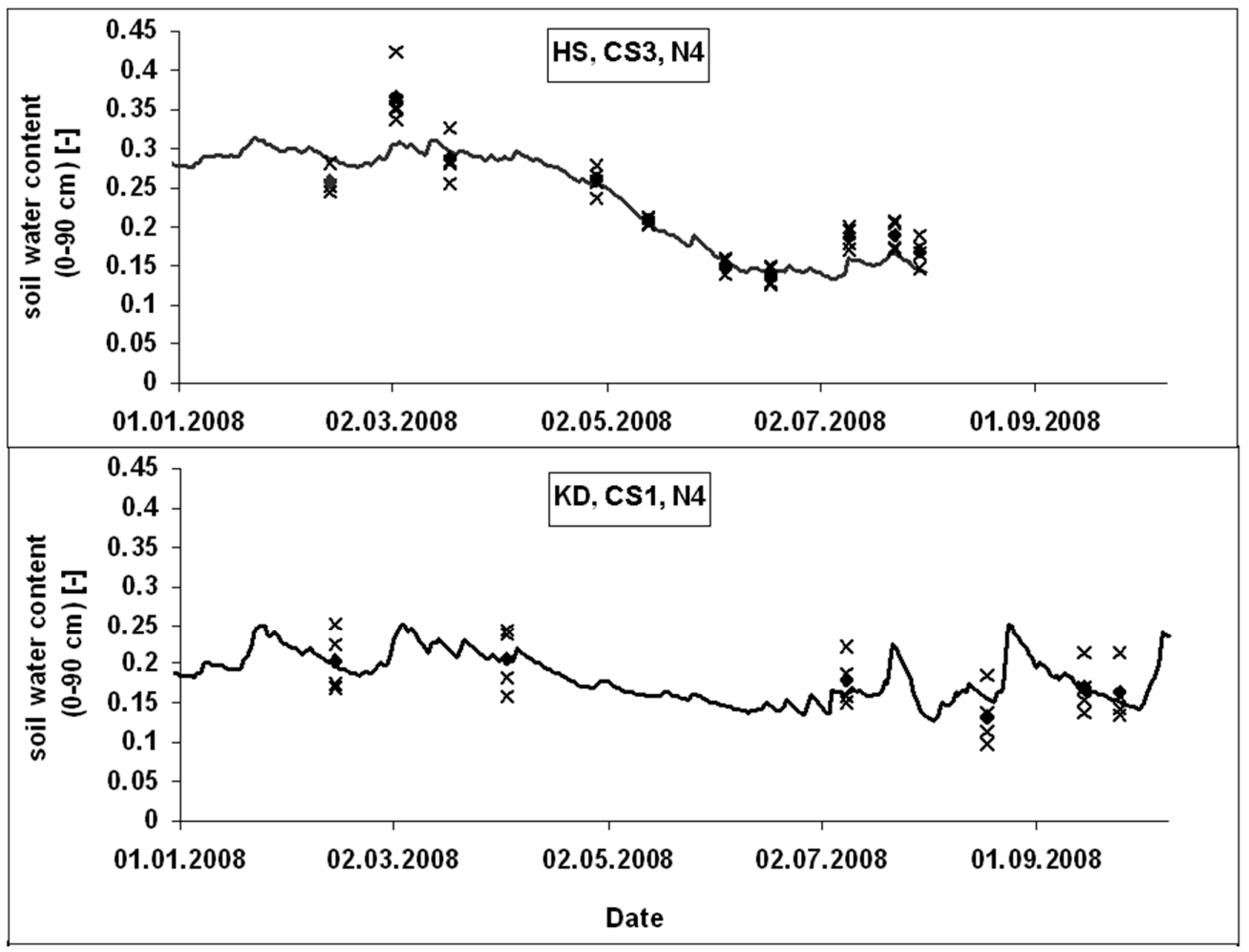

Figure 5. Measured and simulated soil water contents in the soil layer from 0-90 cm over time, based on examples for CS3 (silage maize-winter wheat for grain production, mustard as catch crop), N4 (360 kg N ha ${ }^{-1}$ ) at Hohenschulen (HS), 2008 and CS1 (maize-maize), N4 (360 kg N ha ${ }^{-1}$ ) at Karkendamm (KD), 2008. Lines assign simulation values, crosses assign single measured data points and closed symbols assign the average of the measurements. 
Drainage was substantially different for both sites, with clearly higher values (plus approx. $180 \mathrm{~mm}$ ) calculated for CS1 at KD compared to CS1 at HS (Table 8). A decrease of drainage with increasing $\mathrm{N}$ supply was observed, but not very marked.

For CS4 at KD, a lower cumulative actual evaporation (cum. $E_{a c t}$ ), but a much higher (plus approximately $100 \mathrm{~mm}$ ) cumulative actual transpiration including interception (cum. $\mathrm{TI}_{\mathrm{act}}$ ) was calculated compared to CS1 (Table 8) leading in combination with low DM yields to low values for WUE in CS4. For CS1 the lower cumulative $E_{\text {act }}$ and $T_{\text {act }}$ values at $K D$ together with the only small difference in DM yields resulted in a higher WUE for KD on average over the $\mathrm{N}$ treatments.

Evapotranspiration, cumulative $\mathrm{TI}_{\mathrm{act}}$ and cumulative $\mathrm{E}_{\text {act }}$ were only slightly higher (plus approx. $40 \mathrm{~mm}$ ) for CS4 compared to CS1. At HS, CS2 produced lowest drainage and cum. Eact values in combination with highest cum. $\mathrm{TI}_{\text {act }}$ values (Table 8). CS1 and CS3 showed similar drainage and cum. $\mathrm{E}_{\text {act }}$ values, but CS3 showed slightly higher $\mathrm{TI}_{\text {act }}$ values. The differences in evapotranspiration between the cropping systems grown in HS were also negligible, only CS1 showed a slightly lower (minus approx. $30 \mathrm{~mm}$ ) value.

Table 8. Accumulated values of actual evaporation $\left(E_{a c t}\right)$, transpiration including interception $\left(\mathrm{TI}_{\mathrm{act}}\right)$, total evapotranspiration, drainage, and water use efficiency (WUE) calculated by simulation modelling for the different cropping systems (CS) on the two experimental sites under four different N supply levels.

\begin{tabular}{|c|c|c|c|c|c|c|c|}
\hline Site & CS & N-Level & $E_{\text {act }}\left(\mathrm{mm} \mathrm{a}^{-1}\right)$ & $\mathrm{TI}_{\mathrm{act}}\left(\mathrm{mm} \mathrm{a}^{-1}\right)$ & $\mathrm{ET}_{\text {act }}\left(\mathrm{mm} \mathrm{a} \mathrm{a}^{-1}\right)$ & Drainage $\left(\mathrm{mm} \mathrm{a}^{-1}\right)$ & WUE $\left(\mathrm{g} \mathrm{mm}^{-1}\right)$ \\
\hline \multirow{12}{*}{ HS } & \multirow{4}{*}{1} & 1 & 198 & 307 & 504 & 342 & 2.7 \\
\hline & & 2 & 190 & 327 & 517 & 336 & 3.4 \\
\hline & & 3 & 187 & 333 & 520 & 337 & 3.5 \\
\hline & & 4 & 186 & 337 & 522 & 335 & 3.6 \\
\hline & \multirow{4}{*}{2} & 1 & 209 & 288 & 497 & 338 & 1.7 \\
\hline & & 2 & 176 & 367 & 543 & 301 & 2.7 \\
\hline & & 3 & 166 & 392 & 557 & 288 & 3.2 \\
\hline & & 4 & 166 & 386 & 553 & 293 & 2.9 \\
\hline & \multirow{4}{*}{3} & 1 & 212 & 308 & 520 & 341 & 2.6 \\
\hline & & 2 & 193 & 353 & 546 & 327 & 3.1 \\
\hline & & 3 & 192 & 355 & 547 & 328 & 3.2 \\
\hline & & 4 & 191 & 358 & 549 & 328 & 3.2 \\
\hline \multirow{8}{*}{$\mathrm{KD}$} & \multirow{4}{*}{1} & 1 & 139 & 238 & 377 & 530 & 2.6 \\
\hline & & 2 & 122 & 289 & 411 & 501 & 3.8 \\
\hline & & 3 & 123 & 288 & 411 & 502 & 4.1 \\
\hline & & 4 & 121 & 293 & 415 & 500 & 4.3 \\
\hline & \multirow{4}{*}{4} & 1 & 136 & 237 & 373 & 536 & 0.8 \\
\hline & & 2 & 92 & 346 & 438 & 473 & 2.1 \\
\hline & & 3 & 76 & 382 & 458 & 455 & 2.9 \\
\hline & & 4 & 72 & 387 & 459 & 455 & 2.9 \\
\hline
\end{tabular}

On average, the maize crops had the highest TUE values and grass the lowest (Table 9). The $\mathrm{N}$ response of TUE thereby followed the $\mathrm{N}$ effects on DM yield (Figure 2). Therefore, at KD the calculated averaged TUE values were clearly lower for CS4 compared to CS1 (Table 9) and at HS, TUE decreased in the range CS1 > CS3 > CS2 (Table 9).

Table 9. Transpiration use efficiency $\left(\mathrm{g} \mathrm{mm}^{-1}\right)$ of the cropping systems (CS) in Hohenschulen (HS) and Karkendamm (KD), separated between N-levels.

\begin{tabular}{ccccccc}
\hline Site & CS & \multicolumn{6}{c}{ N-Level } \\
\hline \multirow{4}{*}{ HS } & & $\mathbf{1}$ & $\mathbf{2}$ & $\mathbf{3}$ & $\mathbf{4}$ & Mean \\
& 1 & 4.9 & 6.2 & 6.3 & 6.5 & 5.9 \\
& 2 & 3.4 & 4.5 & 5.2 & 4.6 & 4.4 \\
\multirow{2}{*}{ KD } & 3 & 4.8 & 5.4 & 5.5 & 5.5 & 5.3 \\
& 1 & 4.6 & 6.3 & 6.8 & 7.1 & 6.2 \\
& 4 & 1.6 & 3.3 & 4.5 & 4.4 & 3.4 \\
\hline
\end{tabular}




\subsection{Nitrogen Demand and Nitrogen-Use Efficiency}

Using linear-plateau regressions of DM yield over $\mathrm{N}$ supply, optimal $\mathrm{N}$ supply $\left(\mathrm{kg} \mathrm{N} \mathrm{ha}^{-1}\right)\left(\mathrm{N}_{\mathrm{opt}}\right)$ and fertilizer $\mathrm{N}$ use efficiency ( $\mathrm{Mg} \mathrm{DM}\left(\mathrm{kg} \mathrm{N}_{\text {fertilizer }}\right)^{-1}$ ) (NUE) were estimated for all cropping systems (Table 10). The minimum $\mathrm{N}$ supply for maximum DM yields, $\mathrm{N}_{\text {opt }}$, is indicated by the break point of the function; NUE is determined by the slope of the connecting line between the origin and the break point. $\mathrm{N}$ demand of CS4 at KD, indicated by $\mathrm{N}_{\mathrm{opt}}$, was nearly double that of the $\mathrm{N}_{\mathrm{opt}}$ of CS1 at the same site, whereas NUE of CS1 was 2.3 times higher compared to that of CS4. CS2 at HS showed the lowest NUE and the highest $\mathrm{N}_{\text {opt }}$ compared to CS1 and CS3. NUE and $\mathrm{N}_{\text {opt }}$ of CS1 and CS3 were similar. In addition, $\mathrm{N}_{\text {opt }}$ of CS1 at HS and KD were similar, whereas NUE for CS1 grown at HS was slightly higher due to the higher DM yields.

Table 10. Minimum N supply for maximum DM yield $\left(\mathrm{N}_{\mathrm{opt}}\right)$, resulting from a linear-plateau-regression of dry matter yield over N supply; and fertilizer nitrogen-use efficiency (NUE). $\mathrm{N}_{\text {opt }}$ and NUE are given separate for all cropping systems in HS and KD.

\begin{tabular}{|c|c|c|c|}
\hline Site & CS & $\mathrm{N}_{\text {opt }}\left(\mathrm{kg} \mathrm{N} \mathrm{ha}^{-1}\right)$ & NUE (Mg DM $\left.(\operatorname{kg~N} \text { fertilizer })^{-1}\right)$ \\
\hline \multirow{3}{*}{ HS } & 1 & 144 & 0.130 \\
\hline & 2 & 270 & 0.063 \\
\hline & 3 & 136 & 0.129 \\
\hline \multirow{2}{*}{ KD } & 1 & 154 & 0.112 \\
\hline & 4 & 273 & 0.048 \\
\hline
\end{tabular}

\section{Discussion}

The objective of this study was to analyze cropping systems for biogas production in terms of their productivity, resource use efficiency, and growth limitations. This may contribute to the development of improved cropping systems, avoiding the negative side effects of the prevailing maize dominated systems [3]. The challenge in sustainable bioenergy cropping is to ensure both high yields and reduced environmental effects [43].

\subsection{DM Yield}

Crop rotations including winter cover crops and combining C4 and C3 crops achieved DM yields similar to continuous maize (Figure 2). The productivity of the perennial ryegrass system on the sandy site KD, however, was clearly lower.

A short-term crop rotation experiment with two years of field data, however, is subject to some erratic effects of specific weather conditions and effects of previous crops different from the tested crop rotation. The wheat crop in 2007 was the third successive wheat crop grown at this field, leading to exceptionally low yields due to the known effects of self-incompatibility of wheat $[44,45]$. For the maize systems on the other hand, the duration of the crop experiment was not able to reproduce the known yield decline of maize in monoculture [46]. In general, therefore, higher yields can be expected from the cropping systems including wheat if a longer time period had been tested. Although wheat has the highest grain yield potential at HS, winter rye or winter triticale may have performed better as whole plant silage crops in CS2 due to their more vigorous growth in spring and their higher yield potential in total above-ground DM [47].

\subsection{PAR Interception and LUE}

DM yield is a function of both PAR interception and efficiency of its conversion into biomass (LUE) [48]. The cropping systems tested in our experiment showed a wide range of radiation interception, with a ranking of CS4 > CS2 > CS3 > CS1 (for sites HS and KD) (Table 5). This was mainly caused by differences in the leaf area duration, with the highest values for CS4 followed by CS2 and CS3 and lowest for CS1. Some current studies underline the importance of high leaf area duration for 
high biomass production. Heggenstaller et al. [4] found 25\% higher DM yields in a triticale-maize double-cropping system compared to a sole-grown maize due to higher amounts of PAR interception in the double-cropping system. Dohleman and Long [49] showed that the higher yields in miscanthus compared to maize were primarily caused by a higher leaf area duration. However, in our study, the higher PAR interceptions for CS4, CS2, and CS3 as compared to CS1 did not result in higher DM yields. Consequently, the resulting LUE values of these cropping systems were comparably lower (Table 5). The crops, and consequently the cropping systems, realized high biomass yields therefore by different combinations of fractional light use and light use efficiency (LUE) (Table 5), which were negatively correlated for the cropping systems tested (data not shown).

\subsection{Impact of Stress Factors on LUE}

The lower LUE of the cropping systems partly comprised of overwintering C3 crops may be caused by suboptimal environmental conditions, like low temperatures [50,51] or water deficit [52] and the lower LUE of C 3 crops under conditions suitable for C4 crops [48]. Higher drought stress thereby may be the consequence of higher transpiration caused by the higher radiation interception of CS2, CS3, and CS4 (Table 5). SWDF values for the perennial ryegrass grown at the sandy soil site KD (Table 6) indicate that drought stress was an important factor limiting the potential LUE for this cropping system. For all other cropping systems, drought stress, however, was mild. This indicates that the relatively high water availability at our sites allows, especially in the case of HS, to balance the higher water demand (Table 8) of the crop rotations caused by high leaf area duration. The relative yield level or yield advantage of double cropping systems, however, depends clearly on the availability of sufficient water [6].

The observed small differences in the $\mathrm{f}_{\mathrm{T}}$ values between the cropping systems do in a first view not agree with the hypothesis of a stronger reduction of LUE for the thermophile C4 crop maize at relatively low temperatures [7]. However, it has to be borne in mind that the temperature response functions used to calculate $\mathrm{f}_{\mathrm{T}}$ differed between the crops.

LUE values measured or calculated for C4 crops generally exceed those of C3 crops [53-55], which is in line with our results. The single-crop LUE (Figure 4) fit well into the range of values reported in the literature for these crops [49,50,52,56-59]. The comparatively low LUE observed for the perennial ryegrass and Italian ryegrass may partly be caused by the periodic defoliation and the differences in DM partitioning between shoot and root [60].

\subsection{Impact of N Supply on DM Yields}

The positive $\mathrm{N}$ supply effect on DM yields was, at least in the cropping systems including maize (CS1, CS2, and CS3), mainly due to a clear increase of LUE (Table 5, Figure 4). N supply generally affects LUE by increasing leaf $\mathrm{N}$ content per unit leaf area [12]. Lemaire et al. [61] describe a reduction of resource use efficiencies while maintaining leaf area as a typical response of maize to $\mathrm{N}$ limitation. Akmal and Janssens [60] found for C3 grasses both a reduction of LUE and a reduction of leaf area, fitting well to the results observed in CS4 (Table 5, Figure 4).

$\mathrm{C} 4$ and $\mathrm{C} 3$ crops differed not only in their response to $\mathrm{N}$ supply, but also in the efficiency to use $\mathrm{N}$ for biomass production. Maize, as a C4 crop, showed a higher NUE [62] resulting in lower N optima in CS1. The very low $\mathrm{N}$ fertilizer demand of CS3 for achieving maximum DM yields $\left(136 \mathrm{~kg} \mathrm{~N} \mathrm{ha}^{-1} \mathrm{a}^{-1}\right)$ was a result of a cropping system effect [15]. Averaged over all $\mathrm{N}$ treatments and years, SMN (0-90 cm) in early spring were about $20 \mathrm{~kg} \mathrm{~N} \mathrm{ha}^{-1}, 40 \mathrm{~kg} \mathrm{~N} \mathrm{ha}^{-1}$ and $80 \mathrm{~kg} \mathrm{~N} \mathrm{ha}^{-1}$ following Italian ryegrass (CS2), fallow (CS1) and mustard (CS3) as catch crop, respectively. Mustard apparently reduced $\mathrm{N}$ leaching during wintertime and released the incorporated $\mathrm{N}$ after freezing-off, thus providing it with the subsequent crop [63]. 


\subsection{Water Balance and Transpiration Use Efficiency}

Differences in the green leaf area duration of the cropping systems affected the level and dynamic of PAR interception (Table 5) as well as the amount of transpiration, evaporation, drainage (Table 8) and, in consequence, the level of TUE (Table 9) and WUE (Table 8).

A reduced drainage rate caused by a longer leaf area duration of double cropping systems for bioenergy production and may in some areas subject of critical concern [64], especially in the context of future climate change, but for the experimental sites, groundwater recharge was with $40-50 \%$ of the annual rainfall rate in any case still high enough to ensure a high level of water availability.

Compared to LUE, TUE of the cropping systems raised with increasing proportion of C4 crops in the cropping system due to the TUE values of C4 crops compared to C3 crops $[65,66]$. However, TUE was not only affected by physiological aspects of the crops, but also of the sites. CS1 at KD showed a higher TUE compared to that at HS, which can be explained by higher wind speed at HS, while no differences in saturation deficit were observed (Table 1).

\subsection{Method of Analysis}

Analyzing cropping system effects on resource use efficiencies relies on an accurate estimate of DM or grain yield as the typical output of cropping systems and the inputs on the other hand. Some inputs like the input of $\mathrm{N}$ fertilizer can easily be quantified, but the use of resources like PAR and water require a dynamic approach because it is driven by a continuous process. We combined time series of measured crop state variables with dynamic simulation model components. Other approaches rely on measurements only [67] or use simulation models parameterized to sufficiently depict the crops involved $[68,69]$. We feel that our approach gives additional and more precise options for analyzing resource use than the purely empirical approach while avoiding inevitable prediction errors when using crop models with large numbers of partly unknown parameters. Clearly, the approach used in this study is restricted to analytical applications [24] and cannot be used for predictive purposes. In addition, it can be assumed that investigations over a period longer than that in our experiment might modify the simulations.

In general, it is difficult to transfer results from one site to another due to differing site conditions (e.g., weather, soil). However, combining measured data from the experiment with those of simulation modelling allows this problem to be partly overcome since site conditions can be taken into account [41].

\section{Conclusions}

Our study indicates that crop rotations including winter cover crops and combining C4 and C3 crops can achieve biomass yields comparable to continuous maize due to higher leaf area duration and, therefore, higher PAR interception. However, maize was-in terms of resource use efficiency-the most efficient crop. The potentially higher LUE of the C4 crop maize was not overcompensated by suboptimal environmental conditions like low air temperatures. In addition, the advantage of a high TUE observed for maize was only partly cancelled out by high amounts of evaporation, and WUE values for both single-grown maize crops were higher. Groundwater recharge was mainly site dependent, but on both sites it was higher for maize than for crop rotations and perennial ryegrass, respectively. Finally, at both sites continuous maize was highly efficient in terms of $\mathrm{N}$ use. $\mathrm{N}_{\text {opt }}$ was similar in the maize-maize (CS1) and the crop rotation with mustard as catch crop (CS3), but much higher for the crop rotation with Italian ryegrass (CS2). The investigated perennial ryegrass was clearly less productive compared to the maize-maize, mainly due to very low resource use efficiencies as a result of a combination of genetic, crop management-specific and stress-induced factors. A full assessment of bioenergy cropping systems has to consider further aspects, like nutrient losses, status of soil carbon content, and especially greenhouse gas reduction potential. Approaches that focus on biomass yields and resource use efficiencies are valuable for evaluating bioenergy cropping systems, because they can take into account both economic and ecological sustainability. 
Author Contributions: Conceptualization, H.K.; Software, U.B.; Formal Analysis, B.W. and A.K.; Investigation, B.W.; Writing-Original Draft Preparation, B.W.; Writing-Review \& Editing, K.S.; Supervision, H.K., A.H., and F.T.; Funding acquisition, H.K., A.H., and F.T.

Funding: Financial support for this research was obtained from the 'Program for the Future-Economy' financed by the European Regional Development Fund, which is gratefully acknowledged.

Acknowledgments: The authors gratefully thank Kirsten Schulz, Cordula Weise, and Anna Schwinger as well as the entire team of the experimental farm Hohenschulen for their help in executing the field experiments.

Conflicts of Interest: The authors declare no conflict of interest.

\section{References}

1. Weiland, P. Biogas production: Current state and perspectives. Appl. Microbiol. Biotechnol. 2010, 85, 849-860. [CrossRef] [PubMed]

2. Schittenhelm, S. Chemical composition and methane yield of maize hybrids with contrasting maturity. Eur. J. Agron. 2008, 29, 72-79. [CrossRef]

3. Schittenhelm, S. Effect of drought stress on yield and quality of maize/sunflower and maize/sorghum intercrops for biogas production. J. Agron. Crop Sci. 2010, 196, 253-261. [CrossRef]

4. Heggenstaller, A.H.; Liebman, M.; Anex, P.R. Growth analysis of biomass production in sole-crop and double-crop corn systems. Crop Sci. 2009, 49, 2215-2224. [CrossRef]

5. Karpenstein-Machan, M.; Stülpnagel, R. Biomass yield and nitrogen fixation of legumes monocropped and intercropped with rye and rotation effects on a subsequent maize crop. Plant Soil 2000, 218, 215-232. [CrossRef]

6. Graß, R.; Heuser, F.; Stülpnagel, R.; Piepho, H.-P.; Wachendorf, M. Energy crop production in double-cropping systems: Results from an experiment at seven sites. Eur. J. Agron. 2013, 51, 120-129. [CrossRef]

7. Andrade, F.H.; Uhart, S.A.; Arguissain, G.G.; Ruiz, R.A. Radiation use efficiency of maize grown in a cool area. Field Crops Res. 1992, 28, 345-354. [CrossRef]

8. Brisson, N.; Mary, B.; Ripoche, D.; Jeuffroy, M.H.; Ruget, F.; Nicoullaud, B.; Gate, P.; Devienne-Barret, F.; Antonioletti, R.; Durr, C.; et al. STICS: A generic model for the simulation of crops and their water and nitrogen balances. I. Theory and parameterization applied to wheat and corn. Agronomie 1998, 18, 311-346. [CrossRef]

9. Verheul, M.J.; Picatto, C.; Stamp, P. Growth and development of maize (Zea mays L.) seedlings under chilling conditions in the field. Eur. J. Agron. 1996, 5, 31-43. [CrossRef]

10. Colnenne, C.; Meynard, J.M.; Roche, R.; Reau, R. Effects of nitrogen deficiencies on autumnal growth of winter oil seed rape. Eur. J. Agron. 2002, 17, 11-28. [CrossRef]

11. Lemaire, G.; van Oosterom, E.; Jeuffroy, M.-H.; Gastal, F.; Massignam, A. Crop species present different qualitative types of response to N deficiency during their vegetative growth. Field Crops Res. 2008, 105, 253-265. [CrossRef]

12. Muchow, R.C.; Sinclair, T.R. Nitrogen response of leaf photosynthesis and canopy radiation use efficiency in field-grown maize and sorghum. Crop Sci. 1994, 34, 721-727. [CrossRef]

13. Stöckle, C.O.; Donatelli, M.; Nelson, R. CropSyst, a cropping systems simulation model. Eur. J. Agron. 2003, 18, 289-307. [CrossRef]

14. Dogliotti, S.; Rossing, W.A.H.; van Ittersum, M.K. Systematic design and evaluation of crop rotations enhancing soil conservation, soil fertility and farm income: A case study for vegetable farms in South Uruguay. Agric. Syst. 2004, 80, 277-302. [CrossRef]

15. Herrmann, A.; Sieling, K.; Wienforth, B.; Taube, F.; Kage, H. Short-term effects of biogas residue application on yield performance and $\mathrm{N}$ balance parameters of maize in different cropping systems. J. Agric. Sci. 2013, 151, 449-462. [CrossRef]

16. Sieling, K.; Herrmann, A.; Wienforth, B.; Taube, F.; Ohl, S.; Hartung, E.; Kage, H. Biogas cropping systems: Short term response of yield performance and $\mathrm{N}$ use efficiency to biogas residue application. Eur. J. Agron. 2013, 47, 44-54. [CrossRef]

17. Svoboda, N.; Taube, F.; Wienforth, B.; Kluss, C.; Kage, H.; Herrmann, A. Nitrogen leaching losses after biogas residue application to maize. Soil Till. Res. 2013, 130, 69-80. [CrossRef] 
18. Gericke, D.; Pacholski, A.; Kage, H. Measurement of ammonia emissions in multi-plot field experiments. Biosyst. Eng. 2011, 108, 164-173. [CrossRef]

19. Senbayram, M.; Chen, R.; Wienforth, B.; Herrmann, A.; Kage, H.; Mühling, K.; Dittert, K. Emission of $\mathrm{N}_{2} \mathrm{O}$ from biogas crop production systems in Northern Germany. Bioenergy Res. 2014, 7, 1223-1236. [CrossRef]

20. Claus, S.; Taube, F.; Wienforth, B.; Svoboda, N.; Sieling, K.; Kage, H.; Senbayram, M.; Dittert, K.; Gericke, D.; Pacholski, A.; et al. Life-cycle assessment of biogas production under the environmental conditions of northern Germany: Greenhouse gas balance. J. Agric. Sci. 2014, 152, 172-181. [CrossRef]

21. Böttcher, U. Unpublished work. 2018.

22. Müller, K. Remote Sensing and Simulation Modelling as Tools for Improving Nitrogen Efficiency for Winter Oilseed Rape (Brassica napus L.). Ph.D. Thesis, Christian-Albrechts-University, Kiel, Germany, 2009.

23. Dobson, M.C.; Ulaby, F.T.; Hallikainen, M.T.; Elrayes, M.A. Microwave dielectric behavior of wet soil. 2. Dielectric mixing models. IEEE Trans. Geosci. Remote Sens. 1985, 23, 35-46. [CrossRef]

24. Johnen, T.; Böttcher, U.; Kage, H. An analysis of factors determining spatial variable grain yield of winter wheat. Eur. J. Agron. 2014, 52, 297-306. [CrossRef]

25. Kage, H.; Kochler, M.; Stützel, H. Root growth of cauliflower (Brassica oleracea L. botrytis) under unstressed conditions: Measurement and modelling. Plant Soil 2000, 223, 133-147. [CrossRef]

26. Kage, H.; Alt, C.; Stützel, H. Aspects of nitrogen use efficiency of cauliflower I. A simulation modelling based analysis of nitrogen availability under field conditions. J. Agric. Sci. 2003, 141, 1-16. [CrossRef]

27. Kage, H.; Stützel, H. HUME: An object oriented component library for generic modular modelling of dynamic systems. In Proceedings of the International Symposium Modelling Cropping Systems; Donatelli, M., Villalobos, F., Villar, J.M., Eds.; European Society of Agronomy: Lleida, Spain, 1999; pp. 299-300.

28. Monteith, J.L. Principles of Environmental Physics; Edward Arnold: London, UK, 1973; p. 241. ISBN 0-7131-2931-X.

29. Green, C.F. Nitrogen nutrition and wheat growth in relation to absorbed solar-radiation. Agric. For. Meteorol. 1987, 41, 207-248. [CrossRef]

30. van Genuchten, M.T. A closed-form equation for predicting the hydraulic conductivity of unsaturated soils. Soil Sci. Soc. Am. J. 1980, 44, 892-898. [CrossRef]

31. Wösten, J.H.M.; van Genuchten, M.T. Using texture and other soil properties to predict the unsaturated soil hydraulic functions. Soil Sci. Soc. Am. J. 1988, 52, 1762-1770. [CrossRef]

32. Belmans, C.; Wesseling, J.G.; Feddes, R.A. Simulation model of the water balance of a cropped soil: SWATRE. J. Hydrol. 1983, 63, 271-286. [CrossRef]

33. Beese, F.; van der Ploeg, R.R.; Richter, W. Der Wasserhaushalt einer Löss-Parabraunerde unter Winterweizen und Brache. Computermodelle und ihre experimentelle Verifizierung. Z. Acker-Pflanzenbau 1978, 146, 1-19.

34. Bundesanstalt für Geowissenschaften und Rohstoffe. In Bodenkundliche Kartieranleitung KA5; Druckhaus Thomas Münzer: Bad Langensalza, Germany, 2005.

35. Szeicz, G. Solar radiation for plant growth. J. Appl. Ecol. 1974, 11, 617-636. [CrossRef]

36. Dingkuhn, M.; Johnson, D.E.; Sow, A.; Audebert, A.Y. Relationships between upland rice canopy characteristics and weed competitiveness. Field Crops Res. 1999, 61, 79-95. [CrossRef]

37. Thorne, G.N.; Pearman, I.; Day, W.; Todd, A.D. Estimation of radiation interception by winter wheat from measurements of leaf area. J. Agric. Sci. 1988, 110, 101-108. [CrossRef]

38. Andersen, M.N.; Heidman, F.; Plauborg, F. The effects of drought and $\mathrm{N}$ on light interception, growth and yield of winter oilseed rape. Acta Agric. Scand. B 1996, 46, 55-67. [CrossRef]

39. Sheehy, J.E.; Peacock, J.M. Canopy photosynthesis and crop growth-rate of 8 temperate forage grasses. J. Exp. Bot. 1975, 26, 679-691. [CrossRef]

40. Lantinga, E.A.; Nassiri, M.; Kropff, M.J. Modelling and measuring vertical light absorption within grass-clover mixtures. Agric. For. Meteorol. 1999, 96, 71-83. [CrossRef]

41. Wienforth, B. Cropping Systems for Biomethane Production: A Simulation Based Analysis of Yield, Yield Potential and Resource Use Efficiency; Christian-Albrechts-University: Kiel, Germany, 2011.

42. Loague, K.; Green, R.E. Statistical and graphical methods for evaluating solute transport models: Overview and applications. J. Contam. Hydrol. 1991, 7, 51-73. [CrossRef]

43. Zegada-Lizarazu, W.; Elbersen, H.W.; Cosentino, S.L.; Zatta, A.; Alexopoulou, E.; Monti, A. Agronomic aspects of future energy crops in Europe. Biofuels Bioprod. Biorefin. 2010, 4, 674-691. [CrossRef]

44. Gerlagh, M. Introduction of Ophiobolus graminis into new polders and its decline. Neth. J. Plant Path. 1968, 74, 1-97. [CrossRef] 
45. Sieling, K.; Stahl, C.; Winkelmann, C.; Christen, O. Growth and yield of winter wheat in the first 3 years of a monoculture under varying N fertilization in NW Germany. Eur. J. Agron. 2005, 22, 71-84. [CrossRef]

46. Berzsenyi, Z.; Györffy, B.; Lap, D. Effect of crop rotation and fertilisation on maize and wheat yields and yield stability in a long-term experiment. Eur. J. Agron. 2000, 13, 225-244. [CrossRef]

47. Jørgensen, J.R.; Deleuran, L.C.; Wollenweber, B. Prospects of whole grain crops of wheat, rye and triticale under different fertilizer regimes for energy production. Biomass Bioenergy 2007, 31, 308-317. [CrossRef]

48. Fletcher, A.L.; Brown, H.E.; Johnstone, P.R.; de Ruiter, J.M.; Zyskowski, R.F. Making sense of yield trade-offs in a crop sequence: A New Zealand case study. Field Crops Res. 2011, 124, 171-187. [CrossRef]

49. Dohleman, F.G.; Long, S.P. More productive than maize in the Midwest: How does Miscanthus do it? Plant Physiol. 2009, 150, 2104-2115. [CrossRef] [PubMed]

50. Andrade, F.H.; Uhart, S.A.; Cirilo, A. Temperature affects radiation use efficiency in maize. Field Crops Res. 1993, 32, 17-25. [CrossRef]

51. Louarn, G.; Chenu, K.; Fournier, C.; Andrieu, B.; Giauffret, C. Relative contributions of light interception and radiation use efficiency to the reduction of maize productivity under cold temperatures. Funct. Plant Biol. 2008, 35, 885-899. [CrossRef]

52. Earl, H.J.; Davis, R.F. Effect of drought stress on leaf and whole canopy radiation use efficiency and yield of maize. Agron. J. 2003, 95, 688-696. [CrossRef]

53. Bleken, M.A.; Herrmann, A.; Haugen, L.E.; Taube, F.; Bakken, L. SPN: A model for the study of soil-plant nitrogen fluxes in silage maize cultivation. Eur. J. Agron. 2009, 30, 283-295. [CrossRef]

54. Loomis, R.S.; Amthor, J.S. Yield potential, plant assimilatory capacity, and metabolic efficiencies. Crop Sci. 1999, 39, 1584-1596. [CrossRef]

55. Sun, J.D.; Yang, L.X.; Wang, Y.L.; Ort, D.R. FACE-ing the global change: Opportunities for improvement in photosynthetic radiation use efficiency and crop yield. Plant Sci. 2009, 177, 511-522. [CrossRef]

56. Calderini, D.F.; Dreccer, M.F.; Slafer, G.A. Consequences of breeding on biomass, radiation interception and radiation-use efficiency in wheat. Field Crops Res. 1997, 52, 271-281. [CrossRef]

57. Gower, S.T.; Kucharik, C.J.; Norman, J.M. Direct and indirect estimation of leaf area index, $\mathrm{f}_{\mathrm{APAR}}$, and net primary production of terrestrial ecosystems. Remote Sens. Environ. 1999, 70, 29-51. [CrossRef]

58. Mishra, A.K.; Tripathi, P.; Pal, R.K.; Mishra, S.R. Light interception and radiation use efficiency of wheat varieties as influenced by number of irrigations. J. Agrometeorol. 2009, 11, 140-143.

59. O'Connell, M.G.; O'Leary, G.J.; Whitfield, D.M.; Connor, D.J. Interception of photosynthetically active radiation and radiation-use efficiency of wheat, field pea and mustard in a semi-arid environment. Field Crops Res. 2004, 85, 111-124. [CrossRef]

60. Akmal, M.; Janssens, M.J.J. Productivity and light use efficiency of perennial ryegrass with contrasting water and nitrogen supplies. Field Crops Res. 2004, 88, 143-155. [CrossRef]

61. Lemaire, G.; Jeuffroy, M.-H.; Gastal, F. Diagnosis tool for plant and crop N status in vegetative stage: Theory and practices for crop N management. Eur. J. Agron. 2008, 28, 614-624. [CrossRef]

62. Sinclair, T.R.; Horie, T. Leaf nitrogen, photosynthesis, and crop radiation use efficiency: A review. Crop Sci. 1989, 29, 90-98. [CrossRef]

63. Kulig, B.; Lepiarczyk, A.; Oleksy, A.; Kolodziejczyk, M. The effect of tillage system and forecrop on the yield and values of LAI and SPAD indices of spring wheat. Eur. J. Agron. 2010, 33, 43-51. [CrossRef]

64. Meng, Q.F.; Sun, Q.P.; Chen, X.P.; Cui, Z.L.; Yue, S.C.; Zhang, F.S.; Romheld, V. Alternative cropping systems for sustainable water and nitrogen use in the North China Plain. Agric. Ecosys. Environ. 2012, 146, $93-102$. [CrossRef]

65. Ehlers, W. Wasser in Boden und Pflanze Dynamik des Wasserhaushalts als Grundlage von Pflanzenwachstum und Ertrag; Verlag Eugen Ulmer: Stuttgart, Germany, 1996; 272p, ISBN 3-8001-4118-3.

66. Long, S.P. C-4 photosynthesis at low-temperatures. Plant Cell Environ. 1983, 6, 345-363. [CrossRef]

67. Caviglia, O.P.; Sadras, V.O.; Andrade, F.H. Intensification of agriculture in the south-eastern Pampas: I. Capture and efficiency in the use of water and radiation in double-cropped wheat-soybean. Field Crops Res. 2004, 87, 117-129. [CrossRef] 
68. Probert, M.E.; Carberry, P.S.; McCown, R.L.; Turpin, J.E. Simulation of legume-cereal systems using APSIM. Aust. J. Agric. Res. 1998, 49, 317-327. [CrossRef]

69. Nair, S.S.; Kang, S.J.; Zhang, X.S.; Miguez, F.E.; Izaurralde, R.C.; Post, W.M.; Dietze, M.C.; Lynd, L.R.; Wullschleger, S.D. Bioenergy crop models: Descriptions, data requirements, and future challenges. GCB Bioenergy 2012, 4, 620-633. [CrossRef] 